\title{
ON THE GEOLOGY OF THE REPUBLIC OF COSTA RICA
}

\author{
William M. Gabb \\ Transcripción del manuscrito original por: \\ Oscar H. Lücke, Viviana Gutiérrez \& Gerardo Soto \\ Escuela Centroamericana de Geología, Universidad de Costa Rica \\ Documento original en la bibliotenca del U.S. Geological Survey, \\ bajo la signatura 203(386) gG20
}

The Republic of Costa Rica covers an area of about twenty thousand square miles and comprises all of the lower end of the semi-continental mass of Central America where it narrows to form the Isthmus of Panama. An even better description might be to say that it occupies the widening upper end of the isthmus, at the part where it unites with Central America. Lake Nicaragua and its outlet, the San Juan river separates it, along four fifths of its northern border from the adjoining state of Nicaragua, while its south eastern limits, a theoretical line, dividing it from the state of Panamá, of the Columbian Confederation, have never been decided; and have been for years past, or they promise to be for a long time in the future, the subject of heated disputes and battles. The Atlantic coast is a concave line, trending south east, but little broken by bays or headlands, a nearly continuous sandy beach bordering a succession of swamps and lagoons. The Pacific side on the contrary is much more irregular; a broadly curvy line deeply indented by the gulfs of Nicoya and Dulce and rendered still more broken by prominent peninsulas, the most notable of which is that of Nicoya, bordering the gulf of the same name.

The mountain system is double in its structure, consisting (1) of the uplifted sedimentary mass, joining the continuation of the great back bone of the two continents and represented by the Aguacate mountains and their northern continuation, here more and less hidden by volcanic masses, and running south into the great cordillera which separates Terraba from Talamanca. (2) The volcanic mountains which run transverse to the 
first system, rising like a front wall south of the plains of the Rio Frio and forming the northern border of the elevated valley which contains practically all the Hispano-American population of the country. Subsidiary to the two greater chains, especially to the south and east of this valley, are smaller chains, or rather spurs which run down towards the Atlantic, dividing the watersheds of the numerous rivers. These are of variable height and by no means parallel in their courses, clearly the result of denudation of a great sloping mass, during the gradual elevation of the land.

While the highest land, the summit of Pico Blanco, the culminating point of the mountain, has acquired its elevation by uplift from below, the next highest points have reached their present altitude by superficial accretion. These are the two volcanoes of Turrialba and Irazu. All three of these points exceed 11,000 ft in height. Succeeding them are the two possible volcanoes of U-jum and Lyon and the peak of Herradura, none of which have been ascended and the character of which is therefore yet in doubt. Herradura has been claimed by most writers to be a volcano, but I see no reason for their assumption, beyond its height and the fact that it is in a country of volcanoes. In a country where high mountains cover so much of its area, and where rains are so abundant; rivers must necessarily be numerous and large. The principal one, the San Juan, the outlet of Lake of Nicaragua, forming the northeastern border of the state. One of its outlets, now carrying really the greater part of its water, running entirely in Costa Rican territory is called The San Carlos. The lower part of the San Juan runs entirely through low ground and the two streams are connected by a network of transverse channels which, by exhausting the force of the main stream at its mouth, have caused the silting up and consequent destruction of San Juan, or Craytown harbor.

Draining the north face of the east and west range of volcanoes, and the east face of the range running north to the Nicaraguan frontier are some small streams, the largest of which are the Rio Frio and the Sarapiqui. Of the former, just little is known. Its lands are inhabited by a savage tribe of Indians, rendered utterly intolerant of strangers by the [countless] massacres of their people by every band of "Christians" that has ever attempted to penetrate their country. A trail runs down the latter from the gap between the volcanoes of Barba and the Irazu to the mouth of the river, where the Costa Ricans have a military post and political-penal settlement. It is described as a moderately large and sluggish stream, running through flat ground nearly all of its course.

The Reventazón river runs on the hills in the vicinity of Cartago and receives several large tributaries, emptying into the Atlantic under the name of the Parismina. South of this are two or three large streams and numerous smaller ones. Of the former are the Matina, the Estrella, or the North River, the Telire, or Sixaola and the Tilorio or Changuinola. The two names Sicsaola and Changuinola are given to the mouths of these rivers by the Mosquitos, the former meaning river of Bananas, the latter, river of Changina tribe of Indians. Although these names have appeared on most of the maps, I prefer using these by which the streams are known by the people of the country. "Telirisyuk", given as a synonym by Franzius in Petermann's Mittheilungern, under "Sicsaula", both incorrectly spelled, means "the mouth of the Telire" in the local Indian language.

The mountains are so close to the west cost that but four streams of consequence empty into the Pacific. One, the Barranca drains the western portion of the central plateau, from the vicinity of the capital, San José, breaks trough the Aguacate mountains, receiving tributaries from both faces of that range and empties just below the mouth of the Gulf of Nicoya. The only other large river on this side is that of Terraba, rising on the south side of the high mountains about Pico Blanco and running south west to the coast.

The geology of Costa Rica is extremely simple, the formations being few and the structure with but few complications. The greater part of the rocks are sedimentary, of the tertiary age, the remainder being volcanic comparatively recent origin. The oldest sedimentary rock, that which makes up nearly all of the interior mountain chains and in all probability underlies all the great plains is of Miocene age. It is pushed up into steep dips in the mountains of Talamanca by an intrusion of granitic rocks, which have been 
laid bare by denudation, falls into gentle undulations in the lower hills, and becomes leveled in the flat ground. Bordering this on the coast, are small deposits of later age. Near Moin on the rail road, between there and Limon, there is a deposit of clay of Pliocene age, abounding in fossils. From it I collected the greater part of species, of the appended list. Bordering the Atlantic coast is a narrow strip of Antillite which forms low headlands, and a few reefs and islands. About the Chiriqui and the Boca del Toro lagoons, it is more extensively developed, forming the islands and most of the shore.

The granitic rocks are confined to an irregularly shaped, long, narrow mass which have been intruded after the deposition of the Miocene, forcing the central mass up to a height of the nearly twelve thousand feet. This lies entirely in the heart of the high southern mountains, its lowest exposure being not less than three thousand feet above sea level. As will be seen by a reference to the local description portion of this paper, it is in all probability not far below the surface, on the lower part of the course of the Jhorquin river, in Talamanca, and possible may be exposed under the sea near Old harbor. The age of the granitic intrusion is definitely settled by one circumstance. In the immediately overlying Miocene formation, are numerous strata of conglomerate, covering a stretch of more than 100 miles in length. In no part of this conglomerate have I ever seen pebbles of granite, syenite or the cristaline rocks although I have searched carefully for them for nearly two years, over the entire extent of the deposit, Had these rocks been on the surface at the time, the sedimentary deposits would certainly have abutted against them, instead of, as we find them, showing only their under surface in contact; and the presence of contained pebbles of granite etc, would have been inevitable.

Volcanic rocks form a prominent feature in the geology of Costa Rica. Dykes of porphyritic material are common in all of the regions of great and even moderate disturbance. The central valley from the front of Candelaria range northward, and from Sapote to its western extremity, is covered with a sheet of volcanic ash which runs up the east face of the Aguacate mountains, covering most of their summits and even extending in some places down their western flank. The range of mountains bordering the same valley on the north is made up of the same material and, west of the Aguacate range, are stratified rocks, clearly sub aqueous deposits of ashes. In addition to this, the greater part of the range of mountains lying east and north east of the Gulf of Nicoya is known to be of volcanic origin, and future examination may prove it all to have been so formed.

During the somewhat more than two years spent by me in Costa Rica, over eighteen months were devoted to the study of the region, known as Talamanca, about a sixth of the area of the Republic, and lying in its south east corner. In addition to this, I traversed the country, from ocean to ocean, several times between Limón and Punta Arenas, or Puntarenas; made an excursion into Nicoya and some lesser ones in the interiors, including visits to the two volcanoes of Irazu and Barba. Having therefore, copious notes on Talamanca, I shall describe it in as much detail as may be necessary, to give an idea of the general structure of the country, and then add such other observations as I have been able to make on the other parts of the Republic.

The most central point in Southern Costa Rica, the point of origin of two rivers, and the most prominent object in the region is the peak of Kamuk, or Blanco as it is called, by the Spaniards and on the maps. On the $13^{\text {th }}$ of June 1874 , as the head of my party, I ascended this mountain, the first white man certainly, and as far as the knowledge of the native goes, the first human being who had ever stood upon its summit ${ }^{1}$. A narrative of our trip to this mountain would be entirely out of place in this connection, and I shall consequently omit it. It will probably be a long time before another party will follow us. We were three hours on the summit, during which time I took observations for altitude, calculating from an average of about 30 days observations on the coast, principally at Old Harbor. The results gave 11,877.8 feet for the height above the sea. Previous writers, having looked at it from a distance had declared that it was on the ridge, removed from the main chain, that it was an active volcano and even that the bright light of eruptions 
had been repeatedly seen on this summit. Even Mr. John Lyon, an intelligent person, who had lived seventeen years in the country, and who had formerly navigated the coast as master of a trading vessel, gave me a circumstantial account of an eruption that he thought he saw, from the deck of his vessel, many years before. There could be no doubt as to the light; its origin however was wrongly interpreted. The summit, for nearly a thousand feet is above the line of the forest; and supports a vegetation nearly identical with that of the sage plains of the American desert. The burning of dry Artemisia bushes could give a bright enough light, and that it must have done so, was fully established by the charred trunks we encountered in abundance.

The mountain lies in the line of the granitic protrusion and is the culminating point of the mass. This rock is decidedly syenitic in structure, containing almost no mica, but an abundance of hornblende; resembling closely a similar rock which I found abundantly, and under like circumstances in the Island of Santo Domingo. It is usually however of finer grain, than the West Indian rock and, in the manner of its relation to the overlying rocks, it differs in rarely or never sending out dykes through them. The summit of the peak is divided into two very unequal parts, a long very ragged ridge lying nearly due east and west, convex in the middle and with steep faces; west of this, and separated by a notch, is a sharp conical point, ending above in an oval, convex surface, 30 to 40 feet across and bounded on nearly every side, by precipices. The only side from which it is accessible is on the west, where it is reached by a long and very crooked ridge. [...] trace of a crater but, from the shape of the ridge, it could never have existed. By no stretch of imagination can the present ridge be construed into a part of the rim of a previously existing crater. This whole summit, over half a mile long and nearly a quarter of a mile wide at its base is composed of a dyke of a yellowish grey porphyritic rock, containing small crystals of a dark mineral, probably augite. The rock is a dike projecting above the granite, where it has been left by the denudation of the softer and move easily disintegrated rock. In no respect, except its prominence on the apex of the mountain does it differ from the hundreds of the dykes scattered over the adjoining region, alike in the crystalline and sedimentary rocks. As I have previously announced $^{2}$, Pico Blanco must be removed from the list of volcanoes where it has been placed by every writer from Humboldt down.

The only rocks from the edge of the dyke to a point on the ridge, 3 or 4 miles distant in a straight line, but five days journey by trail, at a place between Isikoilset and Dipuk, in the granitoid rock mentioned above. The surface above the tree line, bearing the desert vegetation, is covered with a layer of turf about foot thick. The tapir makes this a favorite feeding ground and the trails worn by this animal, cut trough the soft turf to the rock, exposing it in innumerable places and giving me a five opportunity to discover ice scratches if they had existed. The repeated assertions made of late, that the glacial period extended over Tropical America; and above all, the statements of Belt ${ }^{3}$ that he had found the proofs of ice action in the gravels of Nicaragua, caused me to search for facts proving or disproving, the theory, as the case might be. Not only did I not find any sign of the former presence of the ice here, but, as I shall endeavor to prove further on, there is every reason to believe that this part of Costa Rica was beyond the ice limit.

The whole north face of the apex of Pico Blanco is drained by the ultimate tributaries the river Lari, one of the main branches of the Telire. From the eastern end of the mountain, a high ridge starts off circling past the face of the mountain and separating the Lari from the head water of the Uren which receives the drainage of the eastern face of the mountain mingling its waters with those of the Lari, below Sipurio. The south side of the mountain is drained by the Terraba river, emptying into the Pacific.

The granite mass runs to the east, in the form of a long narrow tongue, leaving the high ridge of the Cordillera, which trends to the south east, and it finally disappears under the slates just before reaching the Tilorio river. To the north west, it follows the general direction of the mountain summits, in a belt of from three to five miles wide on the Talamanca side. Its extent to the north west, beyond the head of the Telire, and its width on the Terraba side have not been determined. 
From the summit of Blanco, following down the ridge dividing the Uren and Lari, I found several porphyritic dykes in the syenite and one or two in the slates, miles beyond.

While on this ridge, going to and returning from the mountain, we had excellent opportunities of examining, as well as can be done with powerful glasses, at a distance, two neighboring peaks. For the farther of these, nearly twenty miles off, lying on the main ridge, between the head branches of the Coen river, I have retained the native word U-Jum, the only title by which it is known, and which is a generic term applied to any naked peak. It is a truncated cone of perfectly symmetrical form, and as seen from Cabecar, on the Coen, one cannot resist the impression that it is a volcano. By leveling across from where we stood, I arrived at an approximate estimate of its height of between 10,000 and 11,000 feet. The same stories are told of it as have already been mentioned with reference to Blanco, but whether or not it is a volcano must rest a moot question until its yet virgin summit shall have been trodden by the feet of an intelligent observer. The same may be said of another peak, a couple of hundred feet lower, lying on a spur of the main chain, a mile or two from it, and between the Lari and its main branch, the Dipori. This being known to the natives also as Ujum (the Ujum of Bribri, to distinguish it from de Cabecar U-Jum, and the U-Jum of Kamuk, or Blanco) I have called it Mt. Lyon after our friend Mr. John Lyon. It is a broad double peak and has not so strongly marked volcanic outline as the Cabecar hills but may yet prove to have a crater. It is the most accessible of all these peaks, the road from Bribri to Terraba running over its shoulder and very near its summit. I had not an opportunity of visiting it and regret it the more because it may be years, before another competent person will visit this remote region. The Indians have a superstitious dread of the summit, about which innumerable stories of horror are told. The trail runs above the tree line and from the time the people emerge into the open sage desert, until they are safe in the woods on the other side. They hurry along with rapid steps, fated breath and averted faces. One old fellow told me that some years ago he went by this route to Terraba, at the time he went over "the mountain was burning" he did not return for "half a moon" and when he passed back it was still burning. "It was not the bushes, but the rocks themselves that burnt", and there was a strong smell of sulphur. I give this story for what it's worth, warning the reader that I have strong doubts of its veracity. Again, if the current stories are to be believed, mephitic gases prevail there. Nine cases have been enumerated to me, of people killed by the "bad air" in traversing the sage region. This is described invariably as puffs of wind from the summit. The accounts of these deaths are too circumstantial to permit me to doubt them entirely. One was given me by more that one person who claimed to have witnessed it. A woman, carrying a baby, as usual on her back, was following some other person on the trail when a sudden little gust of wind blew. As soon as it struck her, she threw down the child and staggered on. The child died at once, and the mother in about three hours afterwards. This could hardly have been carbonic acid gas since, if she was able to walk away, even with difficultly she should have recovered in the fresh air. I merely repeat the stories for what they are worth, not vouching for details, believing that some deaths may have occurred suddenly at the spot, but not pretending to say how or why; possibly from exhaustion on climbing.

Following the ridge below Kamuk, or Blanco down the Uren, just before reaching Dipuk, the granites disappear under slates so highly metamorphosed that the bedding is obscured, beyond the fact that there is always a high dip to the northward. In the bed of the Uren, at the foot of the spur or hill on which Dipuk is situated, there is a more distinctly defined stratification, the slates being rather fine grained, with some beds of sandstone, striking variously from NE to NW and dipping invariably northward. The debris in the river consists of granitic rocks and a very little porphyry, the former often in boulders of three or four yards diameter. All of the canyons in this region are very narrow, deep and crooked. The rocky walls and points which abound on these sides are too sharp and angular to have ever been subjected to the planning and smoothing action of ice, and in no place is there a trace of moraines either terminal or lateral invariably left behind by glaciers.

A short distance from Dipuk, on the little side branch of the Uren called the Oronli, the slates are 
but little metamorphosed, varying from brown to black, the latter yielding a few fossils. I collected here several species which subsequent examination proved to be Miocene, and 2 or 3 well known. These were the first fossils found by me in the region, and surprised me by their Tertiary aspect, since I was by no means prepared to find Tertiary fossils in a rock, only a few miles off carrying large quartz veins, decidedly auriferous. The bedding of the strata was well marked, striking from $\mathrm{N} 40^{\circ}$ to $45^{\circ} \mathrm{E}$, with an average south east dip of $30^{\circ}$, the reverse of what I had found but a mile or two farther south. Following down the river, the trail runs over a high hill, steep on the Oronli side, but with a gentle descent towards the valley. On this hill, as shown both in gullies on its sides, and in the section shown by the [river], there is a broad anticlinal, the rocks dipping low towards the north and North West. But at Sambli not far from the mouth of the cañon the dip is again reversed and the slates disappear; overlying, heavily bedded sandstones come in dipping to the south east. As we proceed down the river, some beds of clay slate appear, interstratified with the sandstone, all somewhat metamorphosed and finally always ascending in the series, heavy strata of a coarse conglomerate cross the river, striking $\mathrm{N} 70^{\circ} \mathrm{E}$, with a dip of from $40^{\circ}$ to $50^{\circ} \mathrm{SE}$. This, with beds of sandstone, continues to the margin of the hills, the upturned edges disappearing under horizontal beds of gravel of modern origin.

The section on the Lari is similar in character. On entering the cañon, the first rocks encountered are very heavily bedded sandstone, dipping southward at low angles; near Pelukicha, the slates re-appear, very highly metamorphosed, in some cases to a greenish and grayish semi-jasper. They have an average north west strike dipping at high angles to the north east; while still further up, at Sarbli; on the east side of the river, they strike east of north and dip north west. Here I found small segregated veins of quartz with about $\$ 6 .^{00 / 100}$ of gold to the ton; and in all the small stream, could obtain gold by washing. This is within a mile of the southern limit of the sedimentary rocks. To the west of Pelukicha, on the little river Duedi, gold occurs in the bed of the stream in sufficient quantities to warrant mining on a small scale. I found specks in every pan full of the dirt washed.
Still further west, on the Coen, the rocks are similar on the lower river, to those already described. Shales predominate, and the same series of short folds occur as on the other two rivers. A mile and a half above Lotsinyuk, on the mouth of the Lotsi, there is a dyke of porphyry striking south west. The matrix is brown, with large crystals of white glassy feldspar. The shales are burnt-red in the vicinity of the dyke. In addition to many pebbles of conglomerate in the river, I found one or two of calcareous sandstone containing the same species of fossils as those from Oronli.

Above Lotsinyuk, there is a stream emptying into the Coen, so saturated with calcareous matter that it deposits a coat of lime on every object immersed in it. Sticks, stones, land shells are so enveloped that their original form is sooner or late obliterated. I picked up a Helix coated inside and out to a thickness of nearly a quarter of an inch.

At Akbeta, on the west side of the Coen I found a vein of impure limonite cropping out on the hill side, several feet thick, its dark color showing by strong contrast against the slightly altered light brown shales. The trail runs close to it and I had a good opportunity of following it. Even apart from its distance from the coast, it is not pure enough to be of economic value. At San José Cabecar, the site of a long since abandoned mission, the rocks are so altered that their original character and bedding are completely obliterated. In some places they are semi-crystalline. Further up the river and on the largest eastern branch, the Boali, I found only jaspery slates in place, but the great quantity of granitic debris indicated the close proximity of that rock. In addition to this, I found boulders of jaspery slate, highly metamorphosed conglomerates and sandstones and a little porphyry in the Boali.

I did not penetrate far up the upper part of the Tileri from San José Cabecar, we crossed on the old trail used by the mission, ascending the ridge between the Broali and the next stream further down, the Bebli; part of [one route] being in the bed of the latter. We found no shales in this region, the rocks being but slightly altered sandstones and conglomerates in heavy beds. One good exposure, about 3 miles above the mouth of the Bebli, gave a strike of $\mathrm{N} 40^{\circ} \mathrm{W}$ dip about $35^{\circ} \mathrm{SW}$, showing that this first synclinal, running parallel 
with the margin of the intruded rocks continues equally well marked throughout. The strike, as seen above, curves around from NE to NW, but the fold is continuous. We encountered no granites, syenites or porphyries here. As usual all the pebbles of the conglomerate are of clay or sandy shale or of fine sandstone; clearly derived from the underlying beds of the same formation, with which however, the conglomerate is always perfectly conformable in stratification.

We reached the farthest settlement back in the hills, a simple house called Oruchiko, from which point we went to a little stream called Taberi, emptying into the Tileri. About a mile before reaching the Taberi, I found a small spring of petroleum, oozing not with water into a rivulet. The characteristic odor, color and taste were too marked to be mistaken, and in all respects, even to the geological age of the rocks from which it came, it resembled hundreds of similar springs in California. A very short distance below the mountain of the Taberi, the cañon widens out into a valley, and a narrow tongue of the valley gravels about against the hill, covering all the older deposits.

This completed my observations in Talamanca in this direction. To the east of the Uren, I crossed the mountains to the watershed of the Tilorio, ascending the ridge by way of the Karbli and Dukos rivers, and descending parallel with the Blui, to Bruzhik, the head quarters of the Tiribi Indians. The mouth of the Karbli is nearly opposite that of the Oronli, being a little further up stream. On the Karbli and Dakos, all the rocks are clay slates, in various stages of metamorphosis. On the former, half a mile above its mouth they are decidedly magnesian, the only spot where this character was found in the country. They strike NW standing at high angles and enclose a large vein of quartz which, on examination, proved to be slightly auriferous, probably not rich enough to warrant exploitation, even if it were, well situated.

Descending the ridge on the Tilorio side, in addition to highly metamorphosed clay slates, we passed one porphyry dyke, of light brown colors, containing small grains of feldspar, and in one small branch of the Blui, encountered the last outcrop of syenite. This only showed itself in the bed of the stream. At the top of the hill on both sides, the slates had an average strike of $\mathrm{N} 34^{\circ} \mathrm{W}$ with a high dip to the NE. In the bed of the Tilorio, we found both shales and sandstones, much altered and striking $\mathrm{N} 30^{\circ} \mathrm{W}$ dip $20^{\circ} \mathrm{NE}$. In the debris of the river, above the mouth of the Blui, there are no crystalline rocks; all of the boulders being of jaspery slates, much altered sandstones and a conglomerate of peculiar character. I have just remarked the fact that all the pebbles of the conglomerate of the Telire and Coen can be traced lithologically to the underlying shales and sandstones. On the Tilorio the conglomerates are metamorphosed, but the contained pebbles, while their outlines can be clearly traced by a difference of color, were all evidently derived from the same rock that furnished the cementing mud. This rock, a fine grained shale must have been unaltered, since the effect of the metamorphism is alike on pebble and matrix; and now the rock is mainly a jaspery claystone, mottled by large spots of lighter or darker color, having the shape of pebbles and sometimes showing even the lamination of deposition but absolutely inseparable from the surrounding matrix. They are always small, rarely passing five or six inches in greatest diameter, and are always rounded, the greatest length almost invariably being the line of former stratification.

I only examined two or three miles in all down the Tilorio, and obtained no new facts beyond finding sandstone overlying the shale in one place. From this point, we crossed over the ridge again, this time to the head of one of the branches of the Jorquin, or Choli river. The former, the Tiribi name for the river, is the one generally used, and I have spelled phonetically, using the Spanish sounds of the letters. According to the English sounds it would be more properly Jhorkin. Choli, the Bribri name is only used by the people of that tribe. On the ridge between the two rivers, I found the same succession of shales and sandstones, but could find no good exposures, to ascertain their position. On the Izqui, the largest western branch of the Jhorquin, a couple of miles above its mouth, is a good exposure of coarse conglomerate, striking $\mathrm{N} 25^{\circ} \mathrm{W}$ dipping $\mathrm{NE} 10^{\circ}$. Near this is a spring of slightly sulphurous water, temperature $92^{\circ}$. A little further down the Izqui, the strike swings around to $\mathrm{N} 20^{\circ}$ to $70^{\circ} \mathrm{E}$ dip varying from $10^{\circ}$ to $15^{\circ} \mathrm{NW}$. On the Jhorquin the 
shales strike due $\mathrm{N}-\mathrm{S}$ and dip $\mathrm{W} 15^{\circ}$, one mile below the mouth of the Izqui. A quarter of a mile further down, the strike is $\mathrm{N} 30^{\circ} \mathrm{W}$ dip NE $20^{\circ}$. Below the mouth of the Izqui, on the main river, the rocks are all unaltered and contain numerous fossils, though belonging to but few species, and in a poor state of preservation, though recognizable as old as well known Miocene species, found on the Isthmus. On the Shoai, and below its mouth on the main river. I found little seams of coal but a few inches thick and of very poor quality. The same, or similar seams are reported on about the same line of average strike, in the hills of the lower Tilorio and about the head of Sansan lagoon, a long crooked body of water winding through the swamp between the lower part of the Telire and Tilorio rivers. The rapidly varying strikes and dips of the rock, at this point, despite its low lying position, seem to me to point to some local cause of disturbance. I have given only a few of the measurements taken in the vicinity, many more having been made and all of which served only to show an almost inextricable confusion. From the preceding description, it will be observed that the shale is the lowest member of the formation, lying directly on the granitoid rock on the upper parts of the Tilorio, Uren, Lari, Coen, etc. Further, on the upper Uren near the granite, it is not only unaltered, but contains well preserved fossils. I therefore infer that the granite is not far below the surface on the lower Jhorquin and that the local disturbance are due to this cause.

The great valley of Talamanca is a broad irregularly triangular tract, lying along the courses and between the Telire and its three principal branches, the Coen, the Lari and the Uren. The Upper Telire, the Coen and the Lari, all unite at the same point, and the mouth of the Uren is a mile and a half further down. This valley, at its southern margin abuts against the hills and ends quite abruptly, except on the Tilorio, which it follows, with a tongue like prolongation several miles back along its course. It is covered with a thick deposit of debris brought down by the rivers and spread over it in a broad regular sheet. Near the hills, this deposit is made up entirely of coarse gravel, further out it becomes finer and as we go farther from its source it finally changes to a fine red and brown clay. No stranger proof of the absence of ice, as an element in the forces that have shaped the country, could be had, than is this same deposit. Ice, whether as glaciars on icebergs never sorts its material. Glacial deposits are always made up of material of all sizes and shapes indiscriminately mixed and heaped up or thrown down together. Here, all the material is regularly assorted in a manner that is only done by currents of water. Regularly rounded pebbles, worn smooth by attrition are deposited, the largest near their source, finer material comes next and the finest is carried furthest before it finally settles to the bottom. All is laid in layers, gradually thinning out as we recede from the hills.

Below the valley, following the course of the Telire, low hills cut off the greater part of the recent deposit, and confine it to a narrow strip, bordering the channel of the river. Where it appears, it forms bluff, sometimes reaching a length of ten or a dozen feet and at [Cuabre] twenty feet above the average level of the river. The hills show the shales and sandstones, but little altered and lying in a succession of broad low folds. Below the mouth of the Jhorquin, I found another seam of coal, at the mouth of a little stream, called the Nimalas. In the adjoining shales, were some badly preserved fossils, similar to those of the Jhorquin. Coal also occurs on the Watsu, another small tributary of the Telire, and on the northern face of the Negro hills, at the head of Hone Creek, a stream emptying into the sea a mile or two to the west of Old harbor. None of these spots have large veins, rarely passing a few inches and the coal is soft, friable and impure; utterly worthless for economic purposes. I should not have dwelt on it so much, were it not that is, like the gold of this region, subject of numberless speculative ventures, and efforts have even been made abroad, by persons in Costa Rica, to raise capital to develop the "rich mines of Talamanca", fortunately capitalists understand the meaning of the term "wild cat" as applied to such ventures, too well to be deceived by statements of a person designing or ignorant enough to represent this deposits as being valuable.

Before leaving the description of the interior of Talamanca, I may mention a couple of slight earthquake shakes felt by us, while pursuing our explorations. On August $10^{\text {th }} 1873$, about 9 
a.m. at Sipuri we felt a slight shock coming from SW. This was also felt by my topographical assistant, Mr. Martinez, on the coast at the mouth of North river, where he described it as being a brisk shake, lasting fifteen or twenty seconds, causing tall trees to sway violently, and coming from a little west of south. On the 8th of the succeeding October, at Loternyak on the Coen, we felt another shock, sufficient to sway us all in our hammocks, where we were sitting awaiting breakfast. A basket hanging by a cord 15 feet long from the [rafter] of the house, swung two inches, in a direction $\mathrm{S} 15^{\circ} \mathrm{W}$. All of these shocks point towards Mt Lyon. About the first of the preceding March, I experienced another shock in San José, coming from the direction of the volcano of Irazu. This was strong enough to break some eggs in the market, probably by oversetting the basket in which they were contained, and the hotel Chandelier, hanging three feet from the ceiling, swung an inch each away.

The geology of the coast region of Talamanca, is very simple. At a few points, [...], the vicinity of the Boca del Toro lagoon, Mono point, Manzanillo point, Old Harbor and Cajuita, are low exposures of the coral rock, called by me Antillite in Santo Domingo. It differs in no respect, either in character or origin from the Past Pliocene limestone of Jamaica, Santo Domingo, Cuba, the Bahamas etc. Like in those localities, it is compact and rising in some parts, earthy or chalky in others. It always borders the coast, and runs out in reefs under the sea. In short, it is simply an elevated reef, and at Old Harbor, Cajuita and Limón is still being added to below high water mark. As the last locality I have collected fossils from it on shore, and living corals under water, during extraordinarily low tides.

These pieces of reef are by no means continuous, and are separated by long stretches of sand beach. The thirty miles between Old Harbor and Limón is broken by but a simple point, in all about a mile wide. The reefs, and the Antillite deposits only occur where a hill from the interior reaches the coast, and the rocks have offered a solid bottom for the coral animal to build on. Back of the beaches are long lagoons, some of them as deep as rivers, filled with fresh water, stained a dark brown by the decaying vegetable matter. The lagoons are cut off from the sea by but slightly elevated strips of sand varying from a hundred feet to as many yards in width. These lagoons border broad swamps which extend back to the hills. One occupies nearly all the space between the lower parts of the Telire and Tilorio rivers and extends beyond them, on both sides to some distance. Winding through this swap is a nearly currentless stream, called Sansan lagoon, draining the swamp and emptying into the sea. An almost continuous marginal lagoon connects its mouth, behind the beach, with those of the two neighboring rivers. Other smaller streams empty into these coast lagoons, and only in case of heavy rains, and an extra accumulation of water in the swamp, do they seem to have any current. West of Old Harbor, about a mile and a half is the mouth of Hone Creek, a little river, rising in the Negro Hills, half a dozen miles from the coast, receiving several tributaries and ten coast lagoons. In very dry weather, its mouth is completely closed, while after heavy rains, I have seen it over eight feet deep. In the same way, North on Estrella, Banano and Limon rivers all assist to drain swamps and receive at one or both sides of their mouths, just back from the beach, the water of long river-like lagoons, separated from the sea only by a narrow strip of sand. Not only these longer streams, but several smaller ones, emptying on the beach, have their mouths suddenly deflected to the eastward, by the sand piled up by marine currents. Limon river empties directly under the protection of Limon point and is not deflected; and a low bluff at the east side of North river has prevented this action to some extent, but even there, the mouth of the river is contracted by a promontory of sand projecting from the west side. Banana river has been deflected three miles and then cuts a more direct route across the impediment; but the older outlet keeps open and is navigable for canoes to the mouth, which is occasionally shut up by a dry sand bar, after a long drought.

Further up the coast, beyond Limon, the same condition of affairs continues as far as my observation has extended. Salt creek, or Moin river runs nearly parallel with the beach three or four miles, and the Matina, a stream two hundred feet wide, is deflected an eighth of a mile, separated from the sea only by a naked beach. 
At old Harbor (corrupted into "olhaba" by the Spanish speaking people) there is an extensive deposit of magnetite iron sand, washed up by the sea and forming the entire beach of the little bay. It is fine in grain and of remarkable purity. Its source must be below the sea, probably from a submarine outcrop of granitic rocks. It cannot have been brought to the coast by any stream, since only a couple of small rivulets empty here, having their source in the swamp and carrying none of the sand in their course. The eastern end of the sand deposit abuts against the coral rock, of itself a proof of solid bottom, and the western, slides off into calcareous and siliceous beach sand. Similar deposits, less extensive however, have been reported to me, further up the coast, and on the shore of Lake Nicaragua. In the latter case, the iron may be derived from volcanic rocks (which of course are also possible here) but this is hardly probable on the coast further north.

The outer rim of the broad rocky point which shelters the little port of Limon, and is called by the same name, is made up of coral limestone not older, in its oldest parts than the Post Pliocene, and as has been remarked above, yet growing on its seaward margin. This is elevated in the interior of the peninsula into little hummocky hills rarely more than thirty to fifty feet high and including innumerable small patches of swamps and marshy ground, the favorite haunts of tapir and peccary which, despite the proximity of a population of nearly a thousand human beings at the port, continue to return at the imminent risk of their lives; not seldom sacrificed by amateur hunters.

On the line of the rail road which traverses the root of the peninsula, rarely more than a mile from its northern margin, in several of the cuts, I encountered a deposit of clay lying in broad curves, forming low hills. This deposit furnished me with the great part of the fossils described in the appended chapter on paleontology. The fossils are mostly in a beautiful state of preservation, many of the species yet retaining much of their color, and the valves of the bivalves yet remaining in contact. The upper part of the clays contain corals of the large, compact form, while the cuplike species only, are formed in the lower beds. I did not see this rock in actual contact with the limestone, but from its position, as well as from the gradual coming in of the large corals in the upper beds, and specially in these parts most nearly approaching horizontally also to the outcrops of the limestone., I think there can be little doubt but that the clays are the older of the two. Either this is the case or, what is less probable; they are the more in-shore margin of the same deposit. The fossils too indicate a Pliocene, rather than a Past Pliocene age. The number of extinct species prevents us from putting too modern a date for the deposit. Where the clays are best exposed they lie in a broad curved anticlinal, while the coral limestone is practically horizontal, wherever a cut shows a section. I attribute the hummocky to denudation, so that this does not militate with these veins. It therefore seems that the clays, deposited first, were slightly elevated and thus gave the basis on which the reef was built, lying unconformably on the sloping clay strata.

The surface of the reef has been shaved away by the lateral wave action, leaving a nearly level surface, sloping a very little to the seaward. Some harder lumps have resisted and now stand out, entirely isolated to a height of from six to eight feet, like the island illustrated by Dana in his Manual of Geology (1st Ed.p.657)

From Limon towards the interior, the country is a continuous swamp, most of it permanently under water to the point where the rail-road crosses the Matina river. In the bed of the river, at very low stages of water, small outcrops of the same shale, already described, can be seen lying horizontally and nearly or quite unaltered. Beyond the slightly elevated land bordering the river, the swamp comes in again and continues to Madre de Dios, eight miles west. From there to the Paquare river, the ground is very slightly elevated, undulated by the same rock, lying horizontally, or but slightly disturbed. At the crossing of the Paquare river, there is a little bluff of conglomerate, differing in no respect from that of Talamanca. It is heavily bedded, and so much so that the planes of stratification cannot be satisfactorily determined on the single outcrop. The debris of the river consists entirely of rounded pebbles and boulders of Miocene sandstone. M.A.G. Scherzer, the engineer in charge of this section of the railroad presented me with two specimens of an Echinoderm, found by himself 
a few miles further up the river, while speaking of this river, it may be well to mention a fact for which I am indebted to Mrs.Chas Helinle, one of the assistant engineers of the road. On the lower part of its course, in the flat ground back from the coast, it, and its tributary the Siquieres, are each united with the lower part of the Reventazon, by cross channels. The Siquieres thus discharges part of its water into the Paquare and part into the Reventazón, and the two principal rivers communicate by a transverse canal, the two ends of which are a mile or two below the corresponding mouths of the Siquieres.

After crossing the last mentioned stream, three miles form the Ferry over the Paquare, the road ascends a hill, showing some shale and much heavy bedded sandstone, dipping at low angles to the north east. This continues to Sapote, a favorite stopping place on the road, where the same heavy sandstone, and brown and yellow shale and some impure yellow limestone are exposed in the road cutting, lying almost horizontally, or dipping as usual northward, but little uptilted. Below Sapote, on the Reventazón river, at the base of the same hill, I had an opportunity of examining an extended section. The horizontal distance from Sapote is about four miles, and the vertical not much less than 1000 feet. The limestone of Sapote occurs here, forming bluffs, lying horizontally with the base hidden by a talus. A short distance down the river is an outcrop of coarse sandy shales with occasional pebbles imbedded, and containing numerous fossils, highly characteristic of the Miocene, some first described from Gatun on the Panama R. Road.

This outcrop strikes $\mathrm{N}$ about $70^{\circ} \mathrm{W}$, dipping $50^{\circ} \mathrm{NE}$ at its higher part, had the beds falling concavely until they became almost horizontal before they disappear under the water of the river. Down stream below this, are nearly continuous bluffs of horizontal shale without fossils for about three fourths of a mile. Wherever they are disturbed they show low dips towards the north east, never in the opposite direction. Where these shales end, there is another slight local disturbance, a rounded lump projecting on the river bank with the same beds of sandy shale described above here curving concavely and falling off to the north east, dipping not higher than $15^{\circ}$ to $20^{\circ}$. Here also, I collected the same series of fossils, fully confirming the identity of the rocks of Sapote with all the sedimentary rocks of the interior of Talamanca.

We thus have one formation traced by myself from the middle of the Atlantic slope of Costa Rica to its lower extremity. In addition, in the year 1860, Dr, John Evans, the geologist, was sent by the United States government to Chiriqui, to examine a coal mine offered for sale to the government, for the purpose of establishing a coaling station in the Chiriqui lagoon. On his return, he gave me samples of the coal, which, as well as I remember them, were identical in physical characters with the coal, yet to be described from the Candelaria mountains, near San José. He also gave me his fossils, which I described in the Proceedings of the Philadelphia Academy of Natural Sciences. 1860 p.567. Among them was an Orca which I named, at the time A Chiriquiensis, but which subsequent acquaintance with large suites from other localities, has satisfied me is only a local variety of the well known A. grandis, called by Sowerby, from Santo Domingo, A. patricia, and especially characteristic of the Caribbean Miocene deposits. For further remarks on this shell, see the chapter on fossils.

The question naturally arises, how far does this formation extend. We not only have it carried to Chiriqui by the fossils, the coal and the strike of the beds; but the parties sent to California, by the Isthmus for the Pacific rail road survey sent home paleontological proof of its existence there, at Gatun; and the late Dr. Maack found it extensively developed in the Panamá region. It is not far to presume that it ends abruptly, unless another formation can be shown to cut it off. The volcanic rocks of the central region are poured out or scattered over its surface, and the last seen in the direction of it, it disappears horizontally under the heavy cap of debris from the volcano of Turrialba. In the high valley of the interior, all of the fossiliferous rocks are of the same formation and, where last seen on their northern margin, dip to the north and north east. East of the base of Turrialba, they are horizontal or nearly so, dipping, if at all, to the north and north east also. It is only fair to presume therefore that the broad plains without a hill, to the north of Turrialba, stretching away to Lake Nicaragua are, at least in great part underlain by the same formation, here undisturbed. 
All of the country, from near Sapote to the summit of the Aguacate mountains, except the higher hills bounding the valley on the south, may be concisely described as being covered with a sheet of volcanic ash, varied by dykes of more compact rock of a similar origin. Where the road crosses the Reventazon at Angostura, the river cuts its way through a mass of a solid trachytic porphyry. It forms a gorge a hundred feet deep and a hundred yards wide at the top. The channel of the river is hardly fifty feet wide and the water runs between steep walls of rock. A similar contraction of channel occurs a few miles further up, at Fajardo and the rail road cuttings have disclosed the fact that the rock, here decidedly basaltic, was poured out into a river channel with gravel walls. After a large excavation had been made, carrying the road bed through solid basalt, on the face of a precipitous wall of rock, overhanging the river, a slide occurred. The thin shell of rock above the cutting fell down disclosing only beds of gravel behind it, a fact more interesting to the geologist, than amusing to the unfortunate contractor.

The valley of the Reventazon river above Fajardo, a broad flat, bordered by the hills on the south, the eastern extension of the Candelaria range, and on the north by a table of land of several miles in extent, presents every appearance of once having been a lake. The accumulation of water was doubtless due to the damming of the river by this dyke at Fajardo, the cutting away of which eventually drained the lake, leaving its bottom almost perfectly flat except on the margins, where every stream runs through its ancient delta. On the south side of this plain are numerous streams coming down from the high hills, and each runs through a little valley over which the debris of the respective stream is spread in a manner that clearly points to a sub aqueous rather than a sub aerial method of deposition. No streams of importance empty in the river here, from the north side; but several little cones and vaguely defined pits occur which are almost without doubt miniature volcanoes, now weathered almost out of recognizable shape.

North of the region just described looms up the beautiful cone of Turrialba, the highest volcano of Costa Rica. Its base is so surrounded by high hills that, standing too, as it does on a foundation five thousand feet above the sea it does not look as high as it really is. No accurate measurement has yet been made, but it has been estimated by myself, as well as by two or three other experienced persons as being a couple of hundred feet higher than its neighbor Irazu, or approximately 11,500 feet. The upper thousand feet is entirely naked, and as seen from the east, is a prominence with steep sides and a broadly rounded summit, carrying a little peak on its northern side. From the summit of Irazu, the crater is visible, its eastern and southern walls much higher than the northern and western. Nearly always a little cloud of vapor and smoke can be seen curling up from the cavity and gentleman, connected with the rail road work, stationed at Angostura, have assumed [once] that, at times, they have seen the cloud faintly illuminated at night. Access to the mountain is very difficult. It necessitates a week of hard work on foot, through swamps and forest and some very hard climbing. Nevertheless, people of the country occasionally go to the crater for the purpose of collecting sulphur, which they carry to the towns for sale.

A low ridge, at least three thousand feet below the summit, connects this mountain with its sister peak, the Volcano of Irazu, now so nearly extinct that only after heavy rains, when the funnel like crater has collected an unusual quantity of water and poured it on the heated rocks below, can ever a suspicion of "smoke" or steam be detected. Irazu has been ascended so often and accounts of the visits published by so many tourists, that any description, except purely technical would be out of place here ${ }^{4}$. It is only a dozen miles from Cartago, the second largest town of Costa Rica, with a fair wagon road running through farms to within two miles of the crater. Excursion parties frequently go to a flat near the peak, where even ladies camp out, for the purpose of enjoying the sunrise view from the top, to which they ride comfortably on horse back, returning to Cartago, in time for a late breakfast. The fine volcanic ash making up the broad low slopes of the mountain furnishes as excellent soil, and much of the higher region, from eight to ten thousand feet above the sea is occupied by potato fields, while further down, the staple crop is coffee. The last few hundred feet are above the line of forest; the lower part of this region bearing a scattered growth of coarse grass and thorny bushes, while the upper 
part is entirely naked, a broad sheet of ash pumice and scoria. Like Turrialba and Barba, the southern and eastern rims of the crater are the highest. The crater is a bowl shaped depression, elliptical in outline and about 400 yards across, composed entirely of scoria. The highest part of the rim is about 200 feet above the basin. In the bottom of the crater are several fumaroles, the largest of which is hour-glass shaped, a funnel like opening nearly a hundred feet long and with the sides of loose material, so steep as to render a near approach too dangerous to be attempted. The other openings are comparatively round and but a few feet across. My measurements of the height of the mountain, computed from the average of the observations taken on the coast, and checked by synchronous observations taken by Mr. Maison, an accomplished German meteorologist in San José, gave a height for the apex of the mountain, of 11,356 feet above the sea.

Scattered over the entire surface of the mountain, and the adjoining valley, and disseminated through the ash, are great quantities of blocks of harder materials. Among them may be found nearly all the varieties of volcanic rocks, the most notable of which are pumice, pitchstone, a coarse obsidian, compact scoria.

These masses are not regularly disseminated, lying in patches, often quite isolated. Even as far off as the north flank of the Candelaria mountains, seven miles south of San José, they are found in abundance, while none occur in the vicinity of San José itself, not over a width of several miles, between the Candelaria and the nearest volcano. They also occur again in the plains west of Alajuela, many miles from the nearest volcano. There is no doubt but that at least some of these on the sides of Irazu came from its crater; but it is by no means so clear that these in and around Cartago came from the same source; and it is even more difficult to explain the origin of these on the Candelaria. Many of the patches may have originated locally from dykes, and I am inclined to explain all of the isolated cases on the same way, the more so, since I detected between Alajuela and Atenas, a number of such dykes, cutting through the ash, and even found little volcanic cones on the plains, now denuded out of all recognizable shape and recognizable only by the manner of the disposition of the component rocks. But in the rail road cutting, at the summit between San José and Cartago, where it crosses a spur of Irazu a little over 5000 feet above, the sea, there is clear evidence that masses of several tons weight were thrown this far, and imbedded in the volcanic ash. Here, in one section nearly 100 yards long and over thirty feet high, are the marks of three distinct deposits, made at considerable intervals of time. The ashes do not differ in character in the different layers, but over each one is a line of vegetable soil separating them. The surface layer of soil is black; the other two are dark brown. In bedded in the oldest deposit, I found part of the trunk of a tree, changed to a light brown semi-lignite, its cavities lined with crystals of a white salt, from taste apparently nitrate of soda.

West of Irazu, is a lower mountain, also of volcanic origin, now extinct, its three little craters filled with water. It is called Barba and lies north of Alajuela. Its flanks are made up of ash, so fine as to show but little grit, and changed by time to a rich soil, supporting some of the best coffee plantations in the Republic.

A road runs the grater part of the way up the mountain, the upper part of its course, above the plantation being flanked by pastures. Above this, to the summit, is an unbroken forest, traversed by very few trails, one of which leads along the crest and near the principal crater. This is nearly two hundred feet below the top of a sharp little hill which forms its southern lip, and is now occupied by a round lake a couple of hundred feet in diameter. Barometrical measurements gave me a height of 9076 feet from this lake to which must be added by estimate of 200 feet for the apex of the mountain. East of this are two other hills, each corresponding, as our guide told us, to a lake at its northern base, doubtless also craters.

West of Barba lies the fourth and last volcano of this series; Poas. It is least known of all. The crater lies at its eastern end, and was described to me by an intelligent friend who spent three or four days on the mountain. Like the others, the crater is on the north face of the mountain. To the west of the crater, he said there was a broad field of naked ash. The peak is about the height of Barba. Is so marked on the map of Franzius as having an altitude of $[\ldots]$ 
Poas abuts at its western end, against the Aguacate range and further north, in the direction of that range, are some other volcanic peaks which I have only seen at a distance, but some of which were visited by Prof. Von Seebach, now of Göttingen. The reader is referred for information respecting them, to the paper by that gentleman ${ }^{5}$. In addition to these are said to be some others, lying to the east of the range, but little known and, as yet, never visited.

Besides the volcanoes here enumerated, Herradura, Chiripo, and Robalo have been claimed by most writers as being of similar origin. The first does not look like one and, although its claims have been zealously defended, it is useless to discuss the question until some competent observer shall do as I did with Blanco, have exposure, fatigue and starvation and go to its summit. It will cost all three of the above hardships in full measure, but nothing less will settle the question. My trip to Blanco cost twelve days of the hardest work I ever did in my life, from the last Indian house back in the mountains, going and returning, and the explorer of Herradura needs not count on much less. He will have to do most of the work on foot, accompanied by Indian partners. I would recommend San Mateo as a starting point, from which the first day's journey can be done on Mule back. The partners should be Terraba Indians. Chiripo is a comparatively small peak, out of the line of all of the volcanoes; that is, it lies to the south east of Turrialba, beyond the region of great volcanic disturbance, and is entirely off the direction of the great crack, marked by the line of cones from Poas to Turrialba. It stands entirely isolated from the volcanoes and although always included in the list, its right is open to serious question. So with Robalo to the south east, beyond the Costa Rican limits and back of the Chiriqui lagoon. it is only known by persons looking at it from a distance. Nobody has examined its summit, and now that Blanco has been proven not to be a volcano, Robalo is still more isolated. Its nearest neighbor demonstrated to be volcanic is Turrialba, more than 100 miles off. The volcanic forces in this direction seem to have expended themselves in small dykes, scattered abundantly on the country, but nowhere in groups, or showing a tendency to concentration.
Before resuming a description of the western part of the great central valley, it [might] be best to dispose of the hills forming its southern boundary. The valley of the Reventazon divides up and rises at its eastern end, following the streams which contribute their water to the river and, a few miles west of Cartago, the great valley is divided by a low roll, which separates the Atlantic from the Pacific watershed. From here the Candelaria hills rise to an altitude of a couple of thousand feet above the plain, including between their spurs, several pretty sloping valleys, in a high state of cultivation, and each containing a little village. Two or three roads wind up the mountains, following these valleys to their heads and then climbing the ridges. Scattered over the surface of the ground are large blocks of volcanic rocks, but I never found a dyke in place to which they could be traced. The rocks are brown, red and yellow shales and yellow argillaceous limestones. In the latter I found numerous fossils, similar to these from Sapote, proving the identity of age of the two groups of rocks. At a point seven miles south of San José, and half way up the mountain, there has been a coal mine opened and considerable excavation made, in hope of finding a suitable material for fuel but so far, the owner only is convinced of its value. It is impure, earthy, soft and frail crumbling on exposure to the air and disintegrating almost to dust on being handled. The deposit is about nine feet, from wall to wall, of which about half is coal, the other half, a black carbonaceous shale. It might be used for gas purposes, although is doubtful if imported coals or resin would not be cheaper. The vein, and accompanying rocks, have a strike nearly east and west, and dip south, sometimes as high as $40^{\circ}$.

The soil of the valley between this and San José, and for a couple of miles further north, is a rich black mould produced by the mixture of vegetable matter with the finest kind of volcanic ash. Towards Alajuela several road side quarries show heavy beds of ash, sometimes rudely stratified and from Alajuela to Atenas, near the last base of the Aguacate mountains, the ash is so loose and porous that the surface is deprived entirely of moisture and is practically a desert, over this tract, dykes are numerous and there are many little rounded hills, either former volcanic cones, 
or the harder parts of dykes which have resisted denudation. On the side of the road, cut in the hill side at the crossing of the Rio Grande, opposite the "Garita" an old custom house, is a fine illustration of these infantile volcanoes. A mass of hard lava, with little crystals of feldspar, widens out in a funnel shape at the top, partly overlying form separate layers of ash, all of which incline inwards and end acutely under the margin of the harder mass. The beds of ash are of different colors, and they are full of layers and small masses of porous lava and scoria, pumice, etc.

The Eastern face of the Aguacate mountains is hidden under a continuous sheet of ash which reaches the summit and even extends in places down some distance on the western side. I have examined it along the face, from the main road to a point near San Ramon, in the north western corner of the valley, climbing the face of the range in various places and riding along the summit. On the main road there are numerous exposures, made by the road cuttings and in these, dykes of hard volcanic rock make up more than the half the rock, the remainder being a hard, highly metamorphosed sandstone, the bedding entirely obliterated. North of the road are several mines of both gold and silver. One group of two or three silver mines lies high up on the hills, but a mile from the road, the veins are in the sandstone, these being mostly grey sulphides. Further north, at a distance in a direct line, of 9 miles north east from Esparza, and a little north of east from Puntarenas, is a gold vein, here I had a better opportunity of examining the surroundings. The vein is apparently one of segregation and splits into a number of smaller ones at the top. It lies parallel with the slates which here strike NW with a dip from vertical to $50^{\circ} \mathrm{NE}$. parallel with the stratification and close to the vein is a dyke containing little grains of olivine and small crystals of a red feldspar. One of the tunnels traverses this dyke to reach the quartz. The surface of the ground here is covered with ash, and the discovery of the quartz outcrop was almost a pure accident. No fossils have been discovered in the Aguacate range so that the age of the rock must be left an open question.

After leaving the Aguacate mountains, following the road westward, volcanic ash again appears, covering the whole country. Here however it takes on an entirely new character. It is distinctly stratified, with a definite bedding and is clearly a sub aqueous deposit. At the crossing of a stream near San Mateo, the beds are sorted by the water into different degrees of fineness with a strike of $\mathrm{N} 60^{\circ}$ to $65^{\circ} \mathrm{E}$; dip $\mathrm{N} 20^{\circ} \mathrm{W}$. It is a fine ash of variable colors, and contains grains of pumice. Similar beds occur also near Esparza. I feel inclined to refer [their roots] to those described by Bill in Nicaragua also bearing precious metals. Near the Barranca river, above the crossing of the road, there is a fine grained shale, apparently of the same origin; still finer ash, carried further out to sea by the wind before setting. This strikes $\mathrm{N} 40^{\circ} \mathrm{E}$, dip $64^{\circ}$ to $70^{\circ} \mathrm{NW}$. Between this and the coast are only modern deposits of gravel and sand. There is much coarse gravel in the beds of streams, all of hard volcanic material.

The great peninsula of Nicoya has been but little explored. It consists of ranges of low hills, covered with thorny bushes and scant forest, the result of the comparative dryness that prevails along the whole Pacific coast, I have only visited its margins and cannot therefore say much as to its structure. The little that I have seen of the rocks however, was highly satisfactory. The lithological evidence was conclusive, as far as such evidence can be taken, that the rocks are the same as those of Talamanca. Shale beds metamorphosed exactly like those on the Lari, carried imperfect coal seams. These were found, in the eastern part of the peninsula at Lipanta and strike N38E, dipping $\mathrm{NW}$ about $50^{\circ}$. Other similar coal veins are found on the little rocky islets in the gulf of Nicoya, close to the shore of the peninsula, and present no recognizable points of difference from those on the Atlantic slope of the Republic. At the south end of the peninsula, there is a sandstone, splitting into layers two or three inches thick, the surface often bearing coarse traces of fucoids.

I am indebted to Mr. Wm Wittig, an educated German, the director of the Costa Rican mint, and a gentleman not only directly interested in mining matters, but well informed on geology, for the statement, that the Tertiary coal outcrops above described as extending from Chiriqui to the Matina and thence to San José, can be traced around the north face of the Candelaria mountains, past Aseri and Escasu or Izcasu to the Pacific side. This coal also occurs to the north east of Puntarenas on the hills, 
where the rocks are nearly horizontal, and down the coast at Punta Uvita and several other points. This corroborates my own impressions, that all of the sedimentary rocks of southern Costa Rica are members of one formation. Standing on the summit of Pico Blanco, and looking from the rolling hills of Talamanca on one side, to the nearly level plains of Terraba on the other, and knowing that the granite had been pushed up through the Miocene, which continues uninterruptedly around the eastern end of the intrusive mass; the inference was almost irresistible, that the country to the south of us was of the same geological age of that to the north. It seems almost certain that a sheet of Miocene strata, has been simply pushed up in the middle, where its continuity has been only in part broken by subsequent denudation. It must be understood that this is only offered as a hypothesis. Terraba is yet a virgin field for the geologist and beyond two facts we know nothing certainly of it. The first is the existence of these coal outcrops. The second is the statement of my friend Mr. Müllner of San José, Costa Rica, that in the sands of the Rio Cañas and in the Guabito, in the same vicinity, gold is found. The former is a small stream between the Paquita and Damas, and there Mr. Müllner saw quartz [and] free gold, besides the ordinary placer gold washed from the gravel of the river.

\section{Notas}

${ }^{1}$ See Trollope's West Indies and the Spanish Moin, p.285

${ }^{2}$ Amer. Jour, Sci. 1875, pp 198,320

${ }^{3}$ Naturalist in Nicaragua. p250

${ }^{4}$ See Stephens Central America and Yucatán Vol 1, p 365 and Trollope's West Indies and the Spanish Moin.

${ }^{5}$ Petermann's Mittheilung 